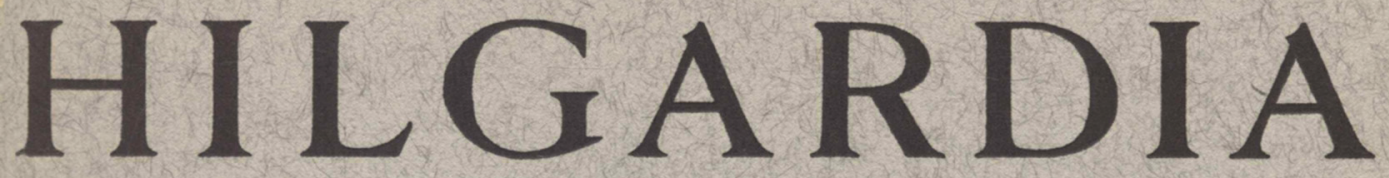

A Journal of Agricultural Science Publisbed by the California Agricultural Experiment Station

\title{
FURTHER OBSERVATIONS ON
}

\section{BACILLUS THURINGIENSIS BERLINER AND OTHER SPOREFORMING BACTERIA}

EDWARD A. STEINHAUS and ELIZABETH A. JERREL 


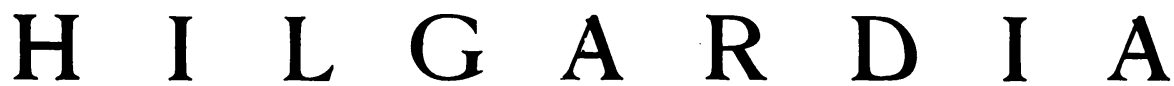

A Journal of Agricultural Science Published by

the California Agricultural Experiment Station

\section{FURTHER OBSERVATIONS ON BACILLUS THURINGIENSIS BERLINER AND OTHER SPOREFORMING BACTERIA ${ }^{1}$}

\author{
EDWARD A. STEINHAUS ${ }^{2}$ AND ELIZABETH A. JERREL ${ }^{3}$
}

\section{INTRODUCTION}

Is 1951 our laboratory reported (Steinhaus, 1951) on some aspects of the biological control potentialities of certain sporeforming bacteria, together with some general considerations of Bacillus thuringiensis Berliner as an insect pathogen and as a possible agent to use in the control of the alfalfa caterpillar. This was followed with similar studies by the senior author's students (Tanada, 1953; Hall, 1954; Clark, 1954) and an associate (Thompson, 1954). In the meantime, we have been making incidental observations on $\boldsymbol{B}$. thuringiensis and its pathogenicity for several species of insects being reared in the laboratory.

Although in their studies on B. thuringiensis, Berliner (1915) and Mattes (1927) noticed that the vegetative remains of the sporulating cells assumed a rhomboid shape, the description by Hannay, in 1953, of "crystalline inclusions" in the sporangium of the organism made room for further interpretations of the data being accumulated on this bacillus. Neither Berliner nor Mattes attributed to these bodies any role in the disease process caused by the ingestion of sporulating $B$. thuringiensis. Hannay, on the other hand, speculated that the inclusions were connected with the pathogenicity of the bacillus. Heretofore our own investigations had never included cytological studies of the bacillus at the stage the inclusions are formed. In retrospect, however, it would appear that these bodies were present in some of our preparations, as evidenced by figures 2 and 3 in our 1951 paper (Steinhaus, 1951). With the staining methods used, however, the free inclusions were not recognized as anything other than part of the "remains of the vegetative cells."

${ }^{1}$ Contribution from the Laboratory of Insect Pathology, Department of Biological Control, College of Agriculture, University of California, Berkeley. Submitted for publication March 1, 1954.

${ }^{2}$ Associate Professor of Insect Pathology and Associate Insect Pathologist in the Experiment Station.

${ }^{3}$ Senior Laboratory Technician. 
The purpose of the present paper is to record briefly our recent observations on the behavior of $B$. thuringiensis and other sporeformers as pathogens of insects, as well as our findings on the crystal-like inclusions in the strains with which we have been working. Some of the observations reported herein are of a preliminary nature and need confirmation. They are reported at this time, however, so as to be available to other investigators engaged in the rapidly expanding research on this interesting sporeforming bacillus.

\section{MATERIALS AND METHODS}

Although workers in our laboratory have, in recent years, isolated several strains of aerobic sporeforming bacteria that have been identified as Bacillus thuringiensis Berliner, many of the data and infectivity tests reported in this paper were obtained by using the Mattes' strain (0-3-30) of the organism, secured by us in 1942 from Nathan R. Smith. Further data pertaining to the source and character of this strain have been given in the 1951 paper (Steinhaus, 1951), and it is presumed that the detailed description given in the paper by Mattes (1927) pertains to it. The sources of other strains and species mentioned in the present report are indicated in table 1.

Infectivity tests were made either by injecting the infectious material with the aid of a Fest-Dutky microinjector (Dutky, 1942) directly into the body cavity of the test insect, or, more frequently, by feeding it to the insect. Feeding the infectious dose was accomplished either by placing it on the mouthparts of each insect and observing the actual ingestion of the material, or by dipping the food plant into suspensions of the material before giving it to the insects. In the latter instance, a small amount of albumin was usually added to the suspension as a spreader.

A number of insect species have been used in our research on sporeforming bacteria. It so happens that in most of the experiments selected for reporting in the present paper, two species were the principal test insects used. These were: the alfalfa caterpillar, Colias philodice eurytheme Boisduval, and the buckeye caterpillar, Junonia coenia Hübner. Only the larval stages were used. These two species were chosen for most of the experiments since one (Colias) is highly susceptible to many species of microorganisms, while the other, (Junonia), frequently exhibits considerable resistance to many of the same microorganisms. For most of the experimentation the larvae were held individually or in small groups in sterilized paper cartons (half-pint size), and the food (sprigs of leaves of alfalfa and plantain) was kept fresh by immersing the stems of the sprigs in water-filled shell vials according to procedures previously described (Steinhaus, 1953).

Microscopical equipment used included a Leitz "Ortholux" light microscope, a Spencer phase-contrast microscope (dark contrast-medium), a Bausch and Lomb DDE microscope with phase objectives, and an RCA electron microscope type EMU-2B.

\section{EXPERIMENTATION}

Infectivity Experiments. The pattern of pathogenicity of $B$. thuringiensis for various groups of insects is already indicated in earlier publications (for 
example, those by Berliner, 1915; Shepherd, 1924; Husz, 1928 ; Metalnikov and Chorine, 1929a; Steinhaus, 1946, 1949, 1951; Steinhaus and Bell, 1953; Faldini and Pastrana, 1952; Tanada, 1953; Toumanoff and Vago, 1952b). The fact that culturally $B$. thuringiensis is indistinguishable from Bacillus cereus Frankland and Frankland has made it important that all bacteria isolated from insects and identifiable as $B$. cereus or its varieties be considered in relation to the properties of $B$. thuringiensis. This was indicated in the earlier paper (Steinhaus, 1951), and more recently by the work of Angus (1953). In this connection, therefore, a few additional observations may be recorded.

In the first place, it is to be emphasized that $B$. thuringiensis possesses its maximum virulence after sporulation has occurred. (When grown on nutrient agar, this usually begins to take place within 48 hours, and is virtually completed within 72 hours, when incubated at room temperature 23 to $25^{\circ} \mathrm{C}$. Sporulation takes place much more rapidly at 35 to $37^{\circ} \mathrm{C}$. In nutrient broth, spores are formed much more slowly in either temperature range than they are on solid media.) The low infectivity of vegetative cells was recognized by Berliner (1915) and Mattes (1927), and our own experience has amply confirmed their observations in this regard. The fact that the crystal-like inclusions appear in the sporangium at the time of spore formation prompted Hannay (1953) to speculate on the possible association of the inclusions with pathogenicity. If, as Hannay suggests, these inclusions contain a virus or principle that determines the bacterium's virulence or pathogenicity, the formation of spores may assume a secondary or mere coincidental status in this regard.

The possible association of the inclusions with the organism's pathogenicity for insects logically suggests the desirability of grouping all sporeforming bacteria according to whether or not they contain the inclusions and, in turn, to relate this to their virulence or pathogenicity for insects. It was decided to do this with all strains of sporeformers currently maintained in our laboratory's culture collection, and tables 1 and 2 record, in the case of each strain, the presence or absence of inclusions and the pathogenicity for Colias and, in so far as has been possible, for Junonia larvae. Unfortunately, at the time these infectivity tests were run, there was not available to us enough insects to test the pathogenicity of all bacterial strains by injection and feeding for both Colias and Junonia. Nevertheless, we feel that the tests run are indicative and, in most instances, clear cut.

By and large, but with certain exceptions, it has been our experience that the direct inoculation of bacteria into the body cavity of the insect is of little value in determining the invasive abilities of a microorganism. Many common "saprophytes" find the hemolymph a satisfactory medium in which to develop to the extent that their luxuriant growth kills the host. Exceptions to this, however, may be noted in table 2 , in which cases certain nonentomogenous strains of sporeformers did not cause the death of Junonia larvae when injected with 0.006 milliliter of a weak suspension of spores. We have noted similar exceptions with certain nonsporeforming bacteria, such as Sarcina lutea Schroeter and certain gram-negative small rods. 
In general, the infectivity tests showed that, of the sporeformers tested, $B$. thuringiensis was by far the most virulent for the two species of test insects. This held true regardless of the source. (The strains of $B$. thuringiensis used were originally isolated from four different host species.) In all these strains the appearance of crystal-like inclusions accompanied spore formation.

In France, considerable work has been done by Toumanoff and Vago (1951, 1952a, b, c, 1953; and Toumanoff, 1953) on a strain of Bacillus cereus which they have named $B$. cereus var. alesti, and which is markedly pathogenic for the silkworm. These workers kindly sent us two transfers of their bacillus so that we might compare it with our strains of entomogenous sporeformers.

Unfortunately, the cultures of alesti sent to us were found to consist of mixtures of three strains, or dissociants, of closely related sporeformers. One of the three harbored the crystal-like inclusion characteristic of $B$. thuringiensis. Accordingly, the infectivity tests recorded in table 1 cannot be accepted as representing a single clone or strain of bacteria. When these original cultures were fed to and injected into the test insects, the Colias larvae readily succumbed to infection. Of 20 Junonia larvae tested with contaminated food, none became infected, although 10 out of 12 larvae injected did die of infection. When the three strains isolated from the alesti cultures were each tested separately in Colias, the most virulent contained the crystallike inclusions, killing 12 out of 18 larvae. The other two strains (distinguished largely by colony morphology and color) showed only slight pathogenicity for Colias (killing 2 out of 20 and 1 out of 15, respectively).

A slight to moderate degree of pathogenicity was observed with certain of the other entomogenous sporeformers tested (see table 1), particularly the three strains of " $B$. ephestiae." These three strains were received in October, 1953, through the kindness of Dr. Ruth E. Gordon. She had obtained them through Dr. P. Thibault of the Pasteur Institute in Paris. The cultures carried the following designations [our own culture numbers follow in brackets]: (1) Bacillus thuringiensis (ephestiae) [0-18-1], (2) Bacillus ephestiae strain 2 [0-18-2], and (3) Bacillus ephestiae strain 3 [0-18-3]. The first of these three strains is probably that referred to by Chorine (1929) as a strain of $B$. thuringiensis isolated from diseased larvae of the Mediterranean flour moth, Ephestia kühniella Zeller. The last two strains are apparently those used by Metalnikov and Chorine in $1929(b)$, and identified as $B$. thuringiensis by Ellinger and Chorine in 1930. The fact that none of these three strains possesses the crystal-like inclusions, would indicate that Ellinger's and Chorine's designation of them as B. thuringiensis would not be in accord with the present concept of the species.

Of the 25 nonentomogenous strains of bacilli tested (table 2), none possessed the crystal-like inclusions characteristic of $B$. thuringiensis and none showed any significant degree of pathogenicity for the two test insects. With two exceptions, the strains of $B$. cereus included in this series of tests were isolated from the soil or air. Strain 0-3-23 (Smith's strain 201) was isolated from a blood culture, and although originally reported to be pathogenic for 
laboratory animals was later found to be nonvirulent (see Smith, Gordon, and Clark, 1952). Whether or not the slight degree of pathogenicity indicated by feeding this strain to Colias larvae is significant is difficult to say at this point. Strain 0-3-39 (Smith's strain 793) was originally isolated from mice that had been inoculated with the blood of human patients. Although one of the 10 Colias larvae to which this strain was fed did succumb to the organism, it is doubtful that this fact is of any great significance as far as the bacillus' general pathogenicity for insects is concerned.

Presence of Toxic Principle. Although the morphological and anatomical aspects of the manner in which $B$. thuringiensis invades its insect host have been studied by such workers as Berliner (1915), Mattes (1927), and Tanada (1953), very little has been learned as to the physiological mechanisms concerned. None of these authors reports a toxin or toxic substance to be associated with the bacillus. Toumanoff and Vago (1952) reported a toxic paralytic effect in silkworms that had been fed cultures of $B$. cereus var. alesti. This observation may be significant in that $B$. thuringiensis is considered to be a form or variety of B. cereus (Smith, Gordon, and Clark, 1952; Steinhaus, 1951). Similarly, Angus (1953) has reported a toxemia and paralysis in silkworms to which he fed cultures of Bacillus sotto auctt. [Ishiwata], also a strain of $B$. cereus. Moreover, he was able to separate from cultures of $B$. sotto toxic material which he thought was probably associated with the crystal-like inclusions described by Hannay.

From time to time during the course of our experiments, toxic manifestations of one sort or another have been observed in association with certain infectivity tests. Although there was some evidence that 48-hour Seitz filtrates of broth cultures of $B$. thuringiensis were to some degree toxic when administered to Colias larvae by feeding or injection, consistent results were not obtained. Careful experiments with Mandler (9-pound candles) filtrates of four-day-old broth cultures gave no clear indication of toxicity when fed (directly and on alfalfa) to or injected (0.006 milliliter) into Colias larvae. The only untoward reaction noted was the failure of the test larvae on the third day to eat their food as well as did the controls.

Thought to be of possible significance in these experiments is the fact that in nutrient broth cultures $B$. thuringiensis produces very few spores in a week's time, whereas on nutrient agar the cells of a seven-day-old culture have virtually all sporulated. Since other experiments have shown that the vegetative cells of this bacillus have little, if any, pathogenicity for insects when fed to them (although they are lethal when injected), it was clear that young broth cultures probably could not be expected to give results other than those obtained. It was soon found that if the broth cultures were incubated at $37^{\circ} \mathrm{C}$ instead of at room temperature $\left(23\right.$ to $25^{\circ} \mathrm{C}$ ), as was the case in the above experiment, the spores formed in about four days. The above experiments were then repeated with filtrates of such cultures but no significant toxic effects were noted in the alfalfa caterpillar.

To be sure, testing filtrates of nutrient broth cultures can be an inadequate means of determining whether or not an organism is capable of producing an exotoxin. Other tests are contemplated. In the meantime, indications that 
under some conditions cultures of $B$. thuringiensis are toxic for certain insects is suggested by observations made incident to other experiments.

For example, in experiments in which Colias larvae are fed or injected with sporulated cultures of the bacillus, it has been observed frequently that in an hour or so after the feeding, the larvae stop feeding and appear to be ill. In fact, a sequence of symptoms often appears as follows: About an hour after the infective feeding, the larvae cease to eat; within two hours the larvae may show signs of diarrhea and vomiting. The anal discharges are fluid and appear to contain abnormally high numbers of the bacteria comprising their normal intestinal flora (small rods and cocci). From two to six hours following the administration of the bacilli, the larvae may become partially paralyzed and have difficulty regaining their normal posture after being placed on their backs. Eventually, usually in two or three days, they die of a generalized septicemia.

Similar symptoms have been seen in the case of Junonia larvae, which are not as susceptible to $B$. thuringiensis as are Colias larvae. Within two hours after an infective feeding or injection, Junonia larvae stop feeding, become diarrheic, and a short time later may vomit and show signs of paralysis. In the latter stage, Junonia larvae may become somewhat rigid and elevate the posterior ends of their bodies. Unlike Colias larvae, those of Junonia are not highly susceptible to $B$. thuringiensis administered orally, and do not readily succumb to infection. It is frequently the case that whereas 24 hours after an infective feeding the gut of a Junonia larva contains many spores and vegetative cells, 48 hours after the feeding only a few spores and vegetative cells appear in the gut, and after four days virtually no $B$. thuringiensis remain in the insect's intestinal tract.

Crystal-like Inclusions. In 1915, Berliner, in his discussion of spore formation in B. thuringiensis, described, in addition to these spores, ". . einem zuerst kugeligen, später runzeligen und unregelmässig rhombisch geformten Gebilde... ," the possible function of which was not indicated. Mattes (1927) illustrates this body and also describes it as characteristically rhombic in form. He speculated that on division of the nucleus of the bacillus prior to spore formation, one chromatinic body was destined to form a spore and the other chromatinic body became a distinguished nucleated cell equivalent which, when it assumed a rhomboid shape, was called a "Restkörper." According to Mattes, who made a detailed study of the cytology of B. thuringiensis, toward the end of spore development the inclusion shrinks somewhat, causing a slight twisting of the spores so that their longitudinal axes no longer correspond to those of the chain of bacilli. It was probably this phenomenon which Smith (see footnote 5, Steinhaus, 1951) and Smith, Gordon, and Clark (1952) referred to as "the tendency of the spore to lie obliquely in the sporangium."

The clarity of Hannay's (1953) observations on the formation of the inclusion at the time of spore formation, and his suggestion that they might contain a virus or be otherwise responsible for the virulence of the bacillus for certain insects, have focused new attention on the cytological characteristics of $\boldsymbol{B}$. thuringiensis. In our own laboratory, up to this time, 
we have been concerned with investigations of the bacillus that did not include cytological studies.

Subsequent to Hannay's initial observations, we made a microscopical survey of 51 strains of sporeformers in our collection. Of the 25 strains isolated originally from insects, 11 possessed the crystal-like inclusions (see tables 1 and 2). All of these were strains that had been identified as $B$. thuringiensis on the basis of their pathogenicity to insects and their similarity to Mattes' strain of this bacterium. The remaining entomogenous strains exhibited varying degrees of pathogenicity for the test insects. None of the 26 sporeformers derived from sources other than insects harbored inclusions and none had the high degree of virulence for the test insects as had the strains of $B$. thuringiensis. Of considerable interest, however, is the fact that we have recently isolated several strains of sporeforming rods from scale-infested leaves of shrubs of English holly (Ilex aquifolium Linn.) growing on the University of California campus. To our knowledge, these plants were far removed from any known source of $B$. thuringiensis, nor were any diseased insects of any kind observed on them. At this writing there has not, as yet, been time to make a thorough study of these bacteria, but they may represent strains of inclusion-bearing sporeformers from a noninsect source.

Except for figures 4 and 5, which represent strains that do not evince inclusions, figures 1 to 16 show various aspects of the morphological character of the inclusions and their spatial relation to the sporangium and spore. From these, from numerous other photographs, and from observations not photographically recorded, a number of general statements are permissible. (Except for figure 16, electron micrographs, all illustrations are of living preparations and photographed through a phase-contrast microscope.)

In the first place, the form of the inclusions by no means always appears rhombic or diamond shaped, although this might be considered its classical configuration, in certain strains at least. Both Mattes (1927) and Hannay (1953) illustrate the diamond-shaped form, and the latter author states that the inclusions he studied "are always the same shape." In our preparations, the shape of the inclusions varied all the way from rhombohedral to rhombus-ovate to rhomboid to rhomboid-ovate to "square" (that is, presumably a cube or a cuboid). These variations may be seen in the many preparations illustrated; figure 11 is a preparation of free inclusions. Occasionally, inclusions were seen in which the rhombic or diamond-shaped forms were extended in the central part taking on, in outline, two additional sides (fig. 15). Rhombohedra, as well as other forms, occurring freely and within sporangia, may be seen in other illustrations. Some of the variations in shape appear to be characteristic of the particular strain involved. Strain 0-3-30, the Mattes strain and presumably the principal one with which Hannay worked, produced the diamond-shaped inclusions as the predominate form (figures 1, 2, and 3). Strain 25-2-1 did likewise, although to a less marked degree (fig. 6). The cube- or cuboid-shaped inclusions were particularly noticeable in strains of the 16-series (for ex- 


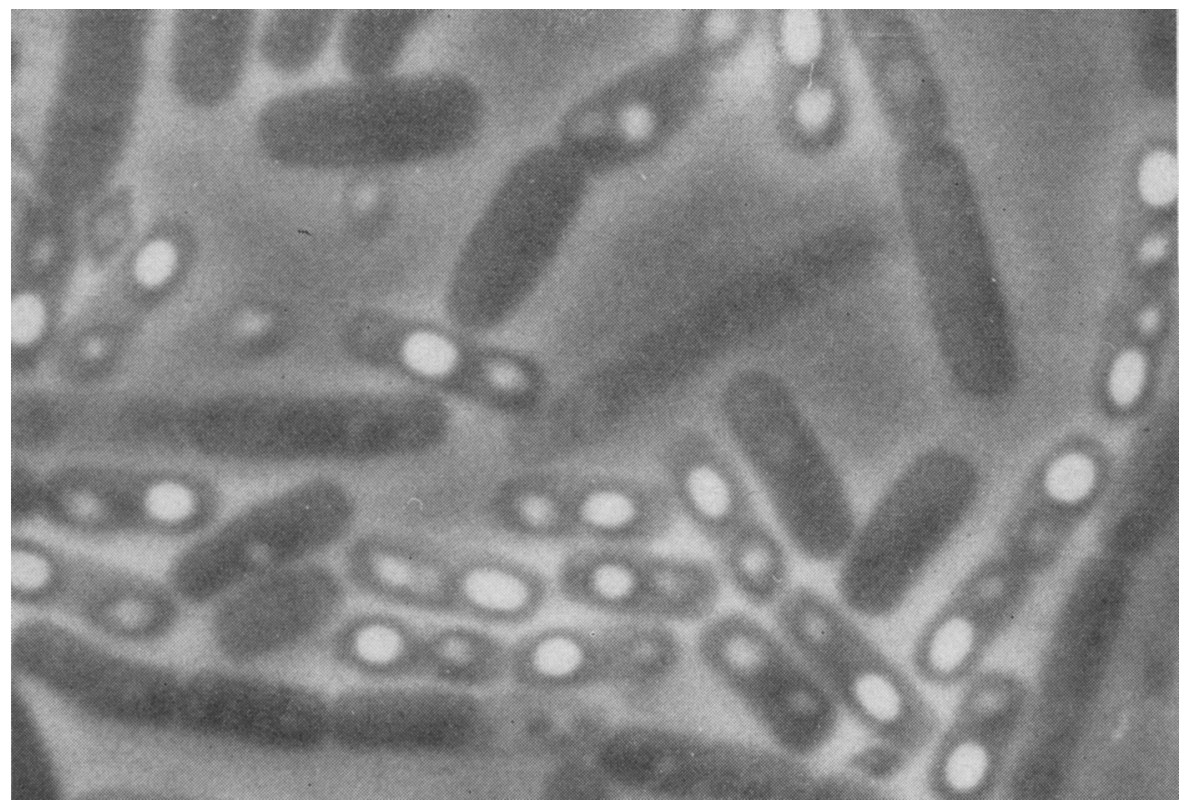

Fig. 1. Strain 0-3-30.

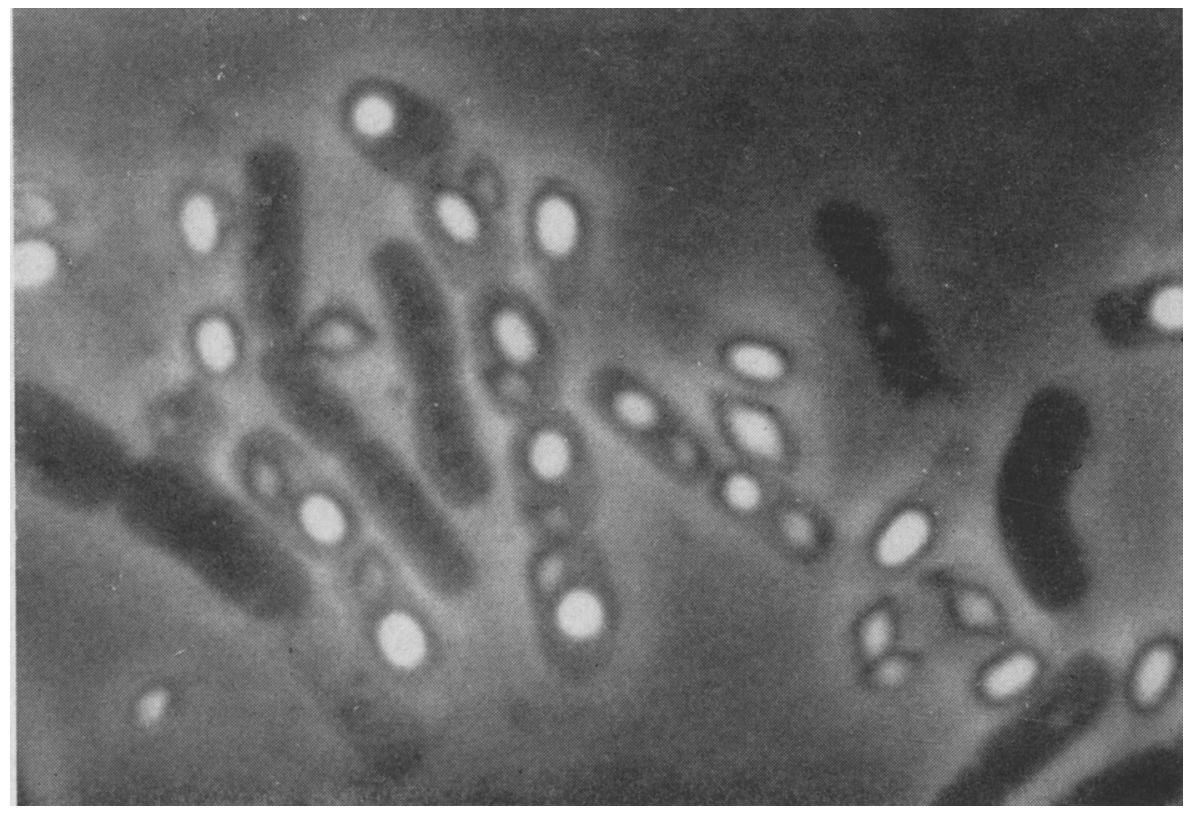

Fig. 2. Strain 0-3-30. 


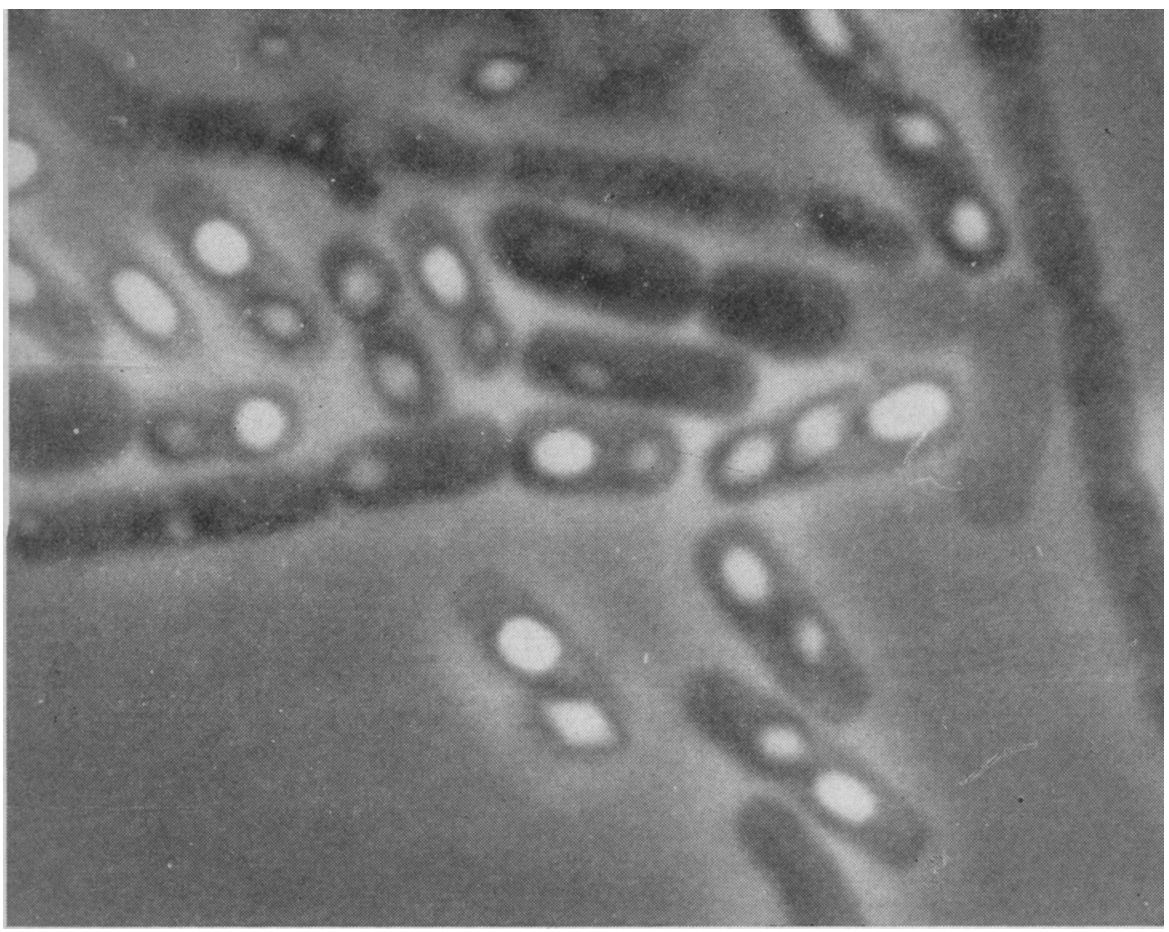

Fig. 3. Strain $0-3-30$.

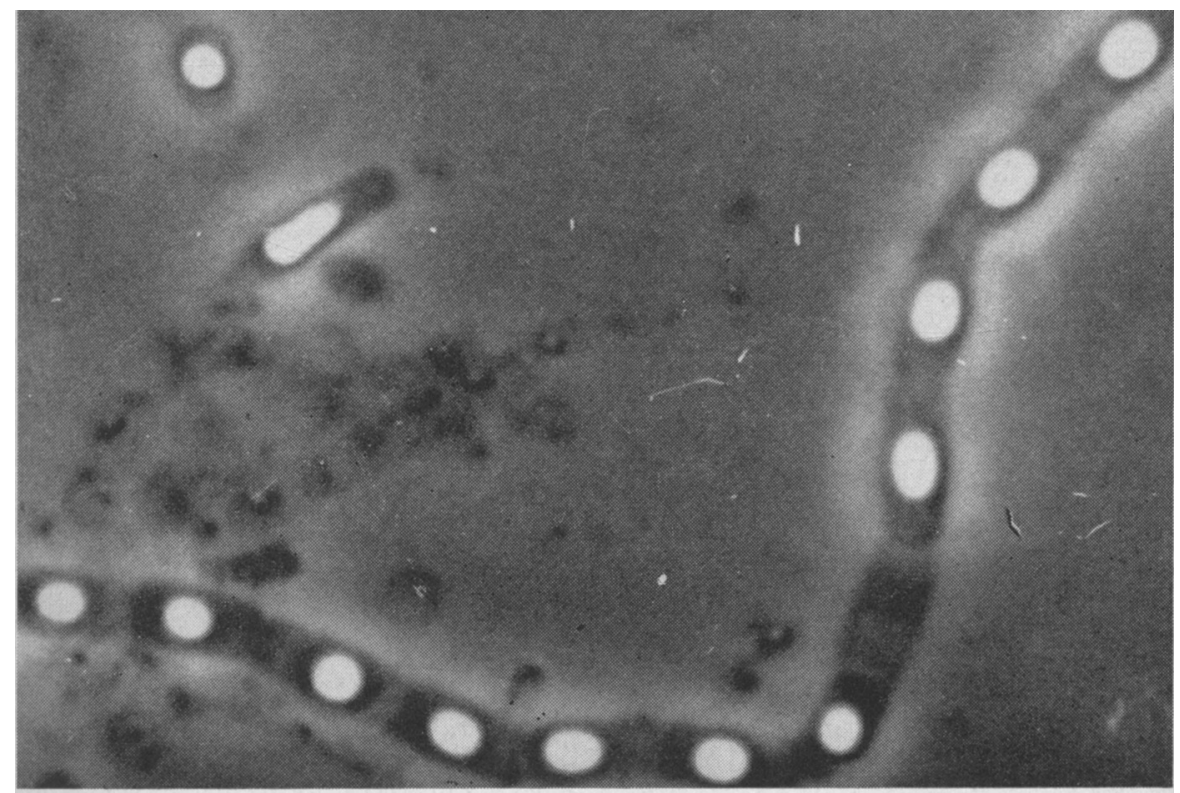

Fig. 4. Strain 0-3-26. 


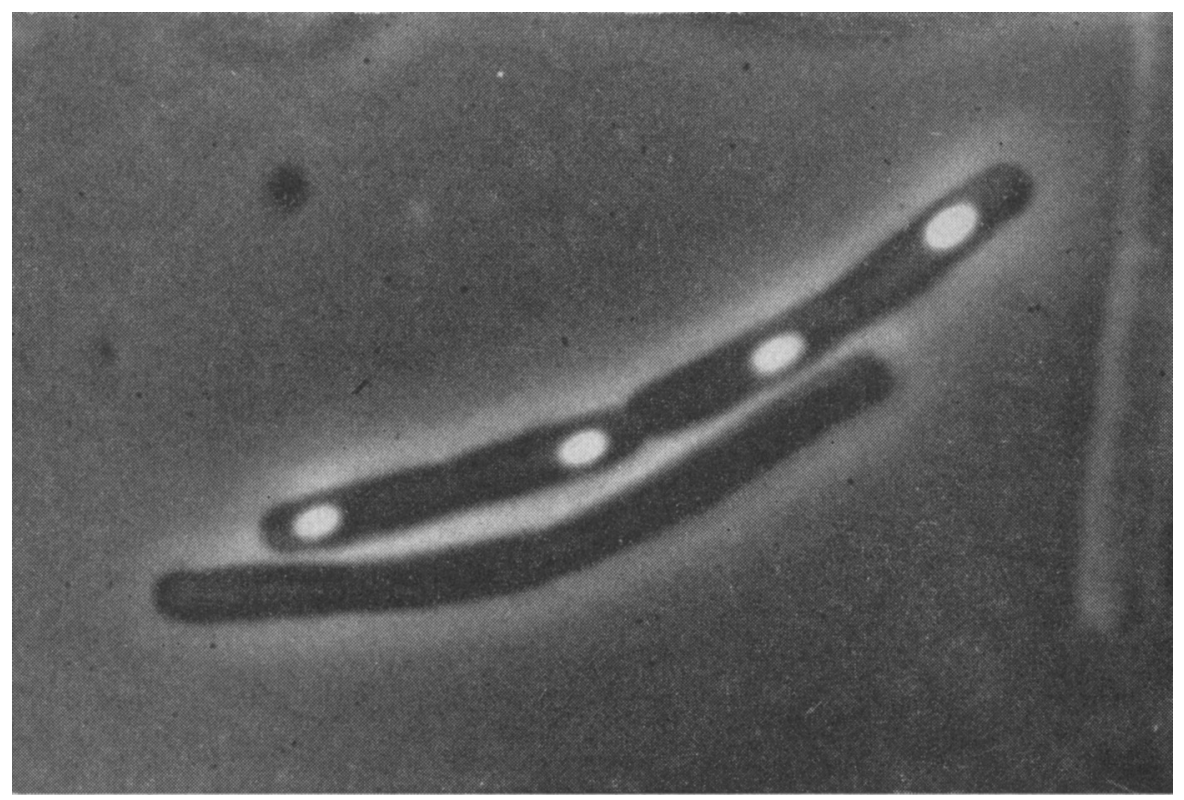

Fig. 5. Strain 0-18-2.

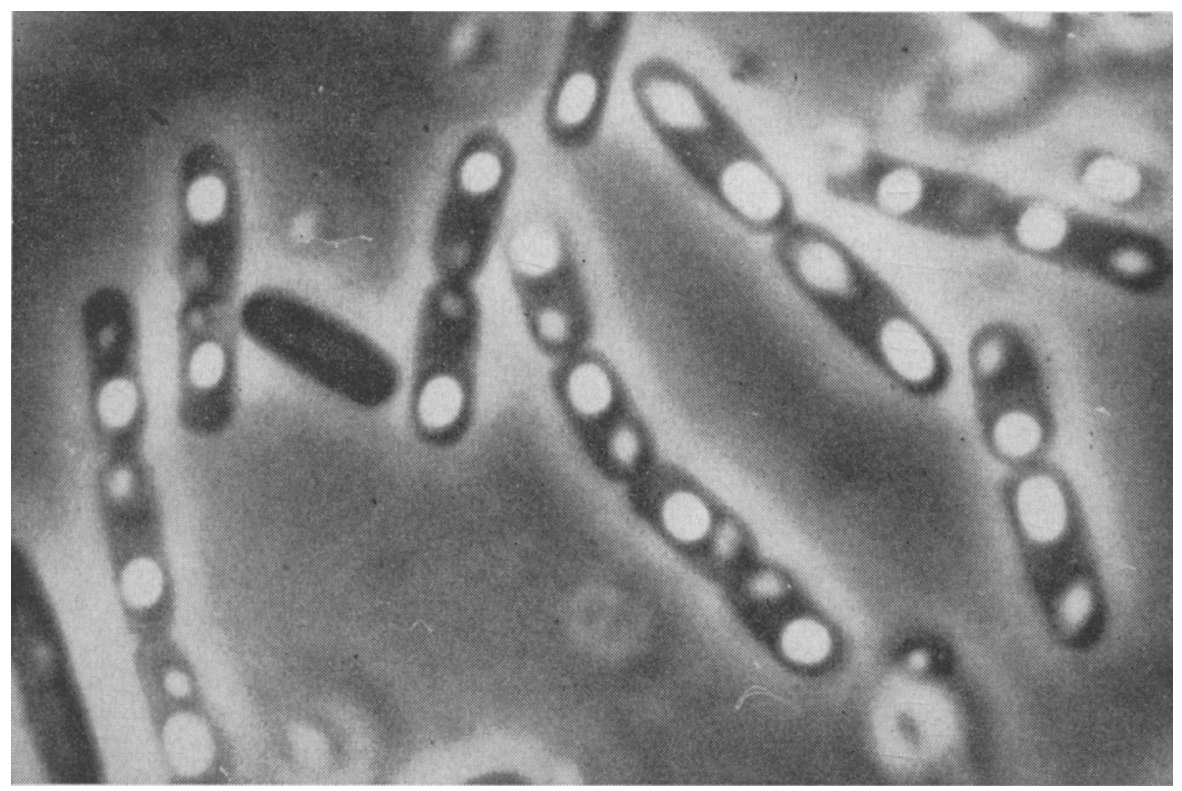

Fig. 6. Strain 25-2-1. 


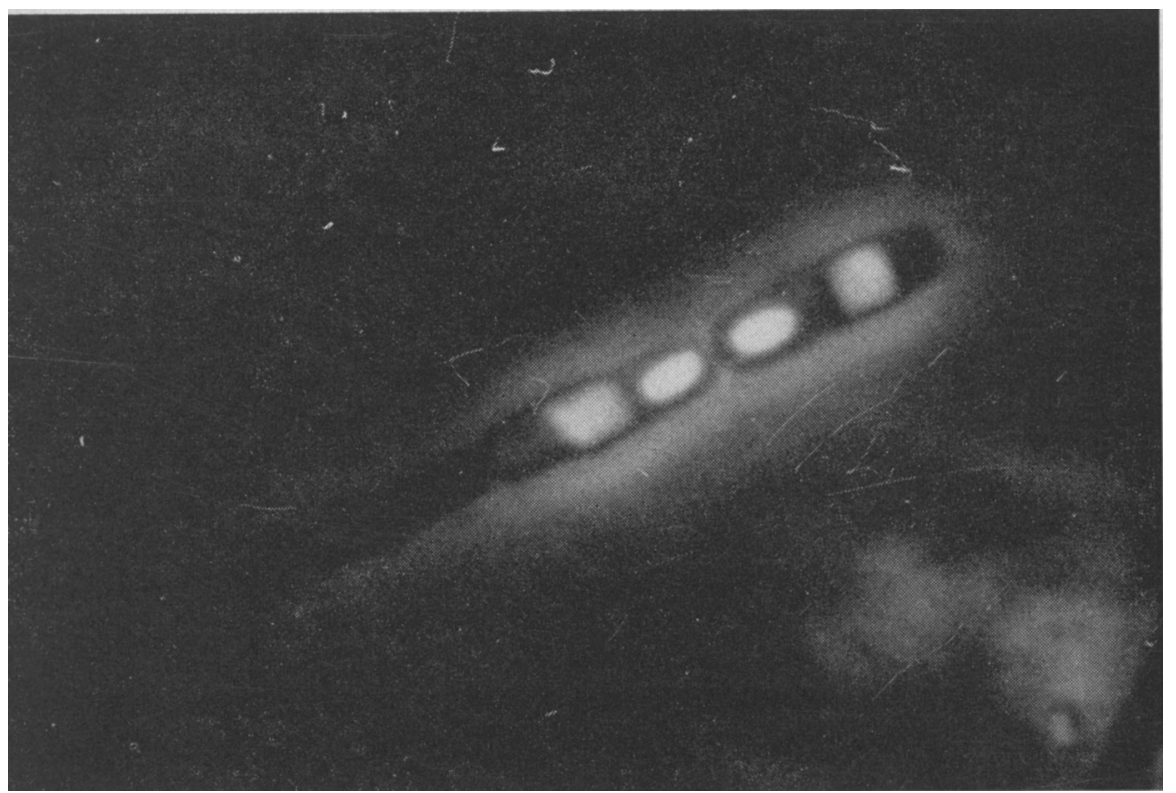

Fig. 7. Strain 16-1-2.

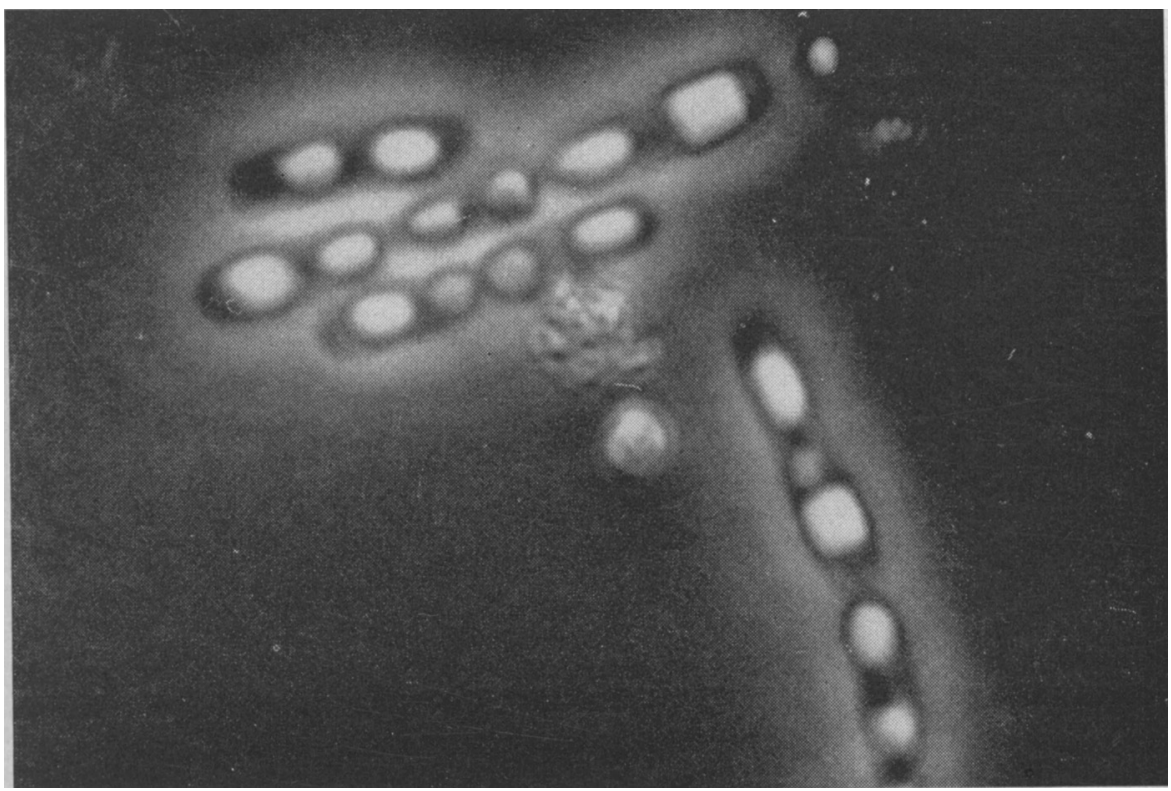

Fig. 8. Strain 16-2-2. 


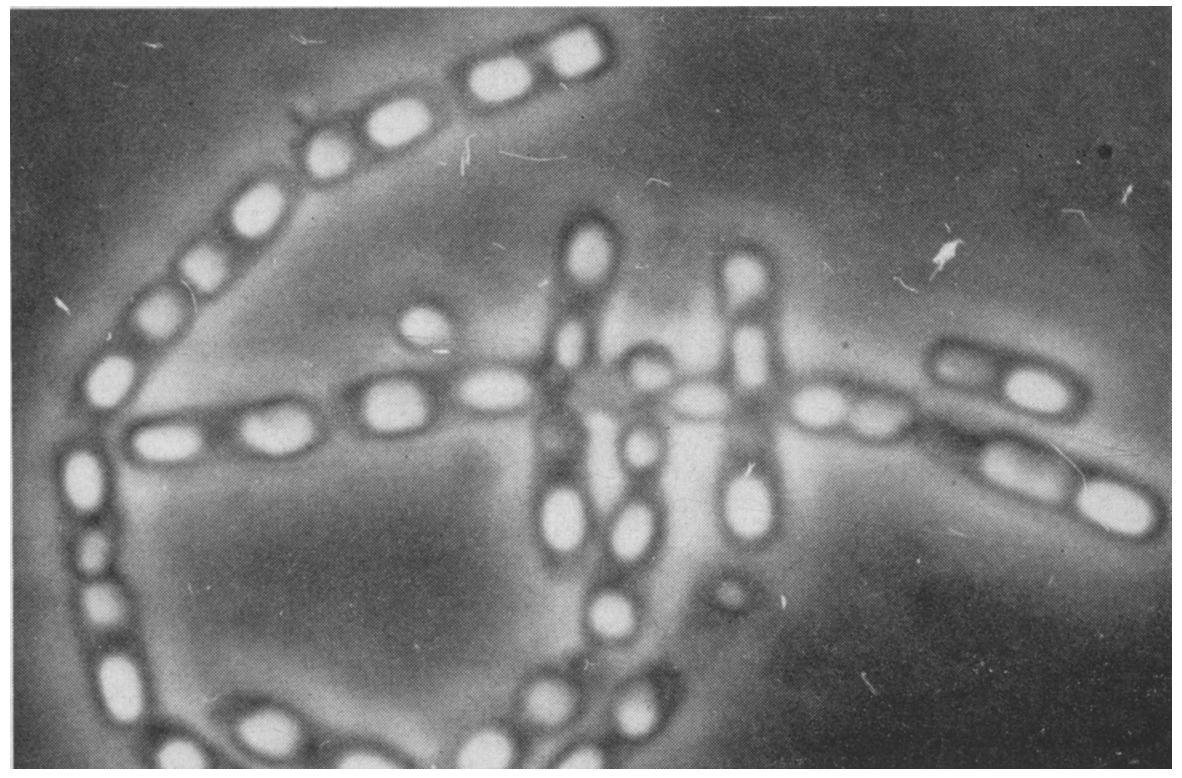

Fig. 9. Strain 16-2-2.

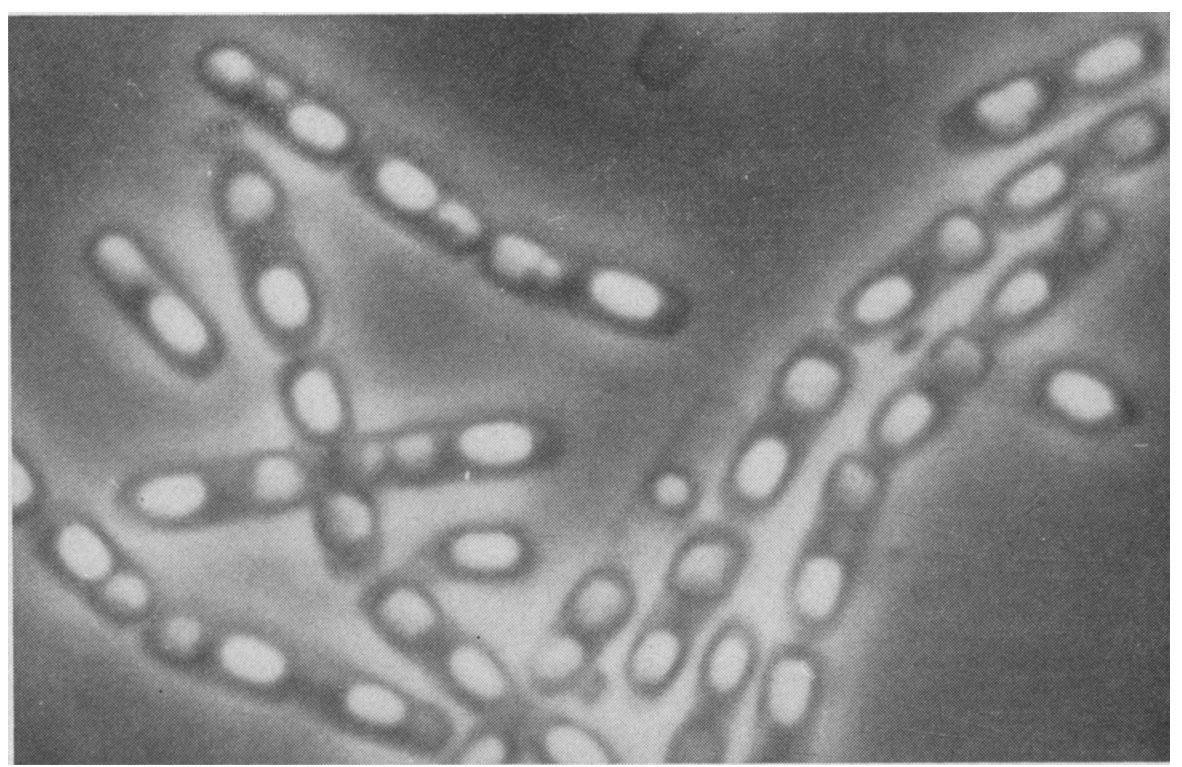

Fig. 10. Stran 16-2-2. 


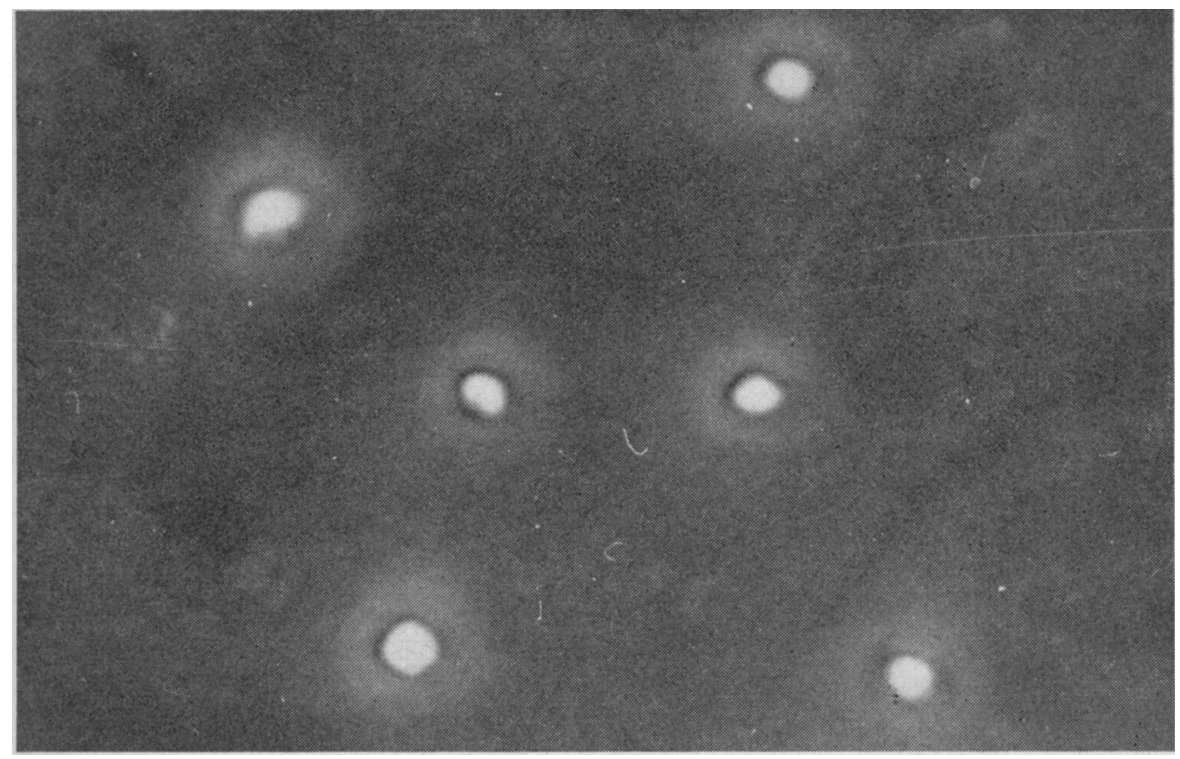

Fig. 11. Strain 16-1-1.

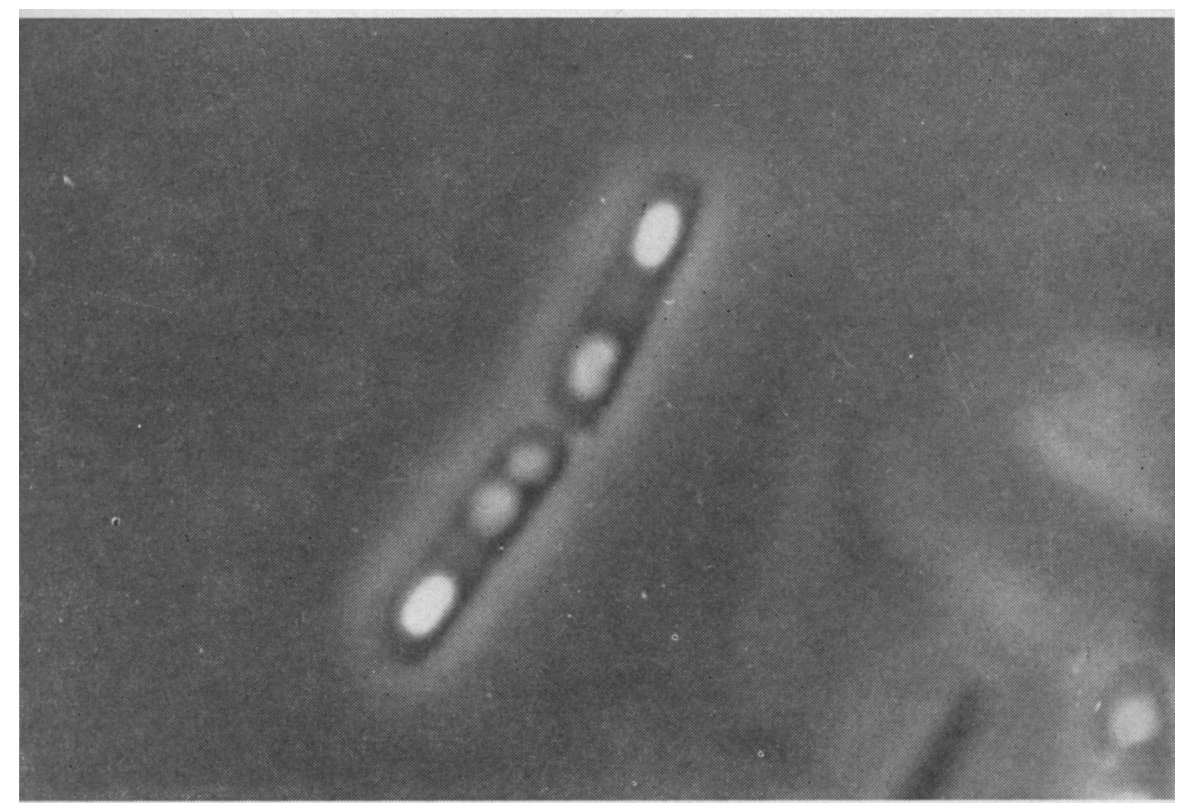

Fig. 12. Strain 16-1-2. 
[Vol. 23, No. 1

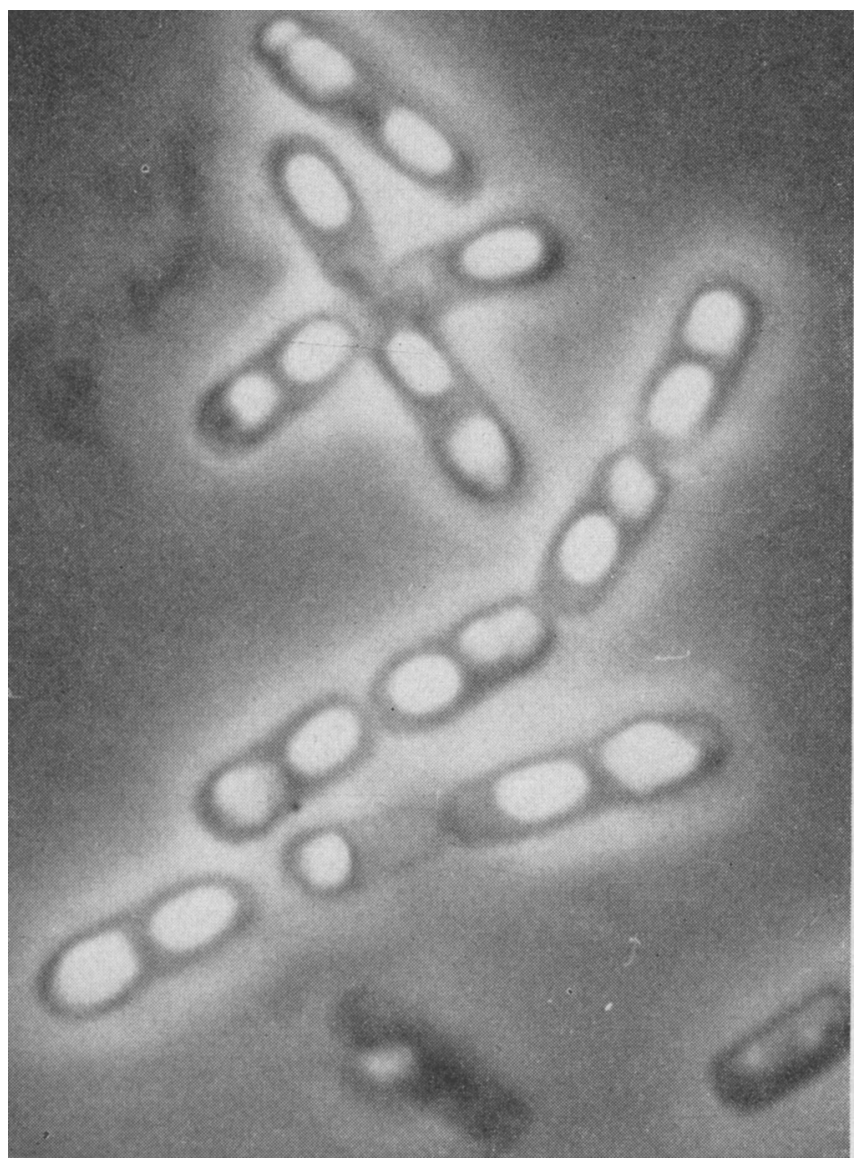

Fig. 13. Strain 16-2-2. 


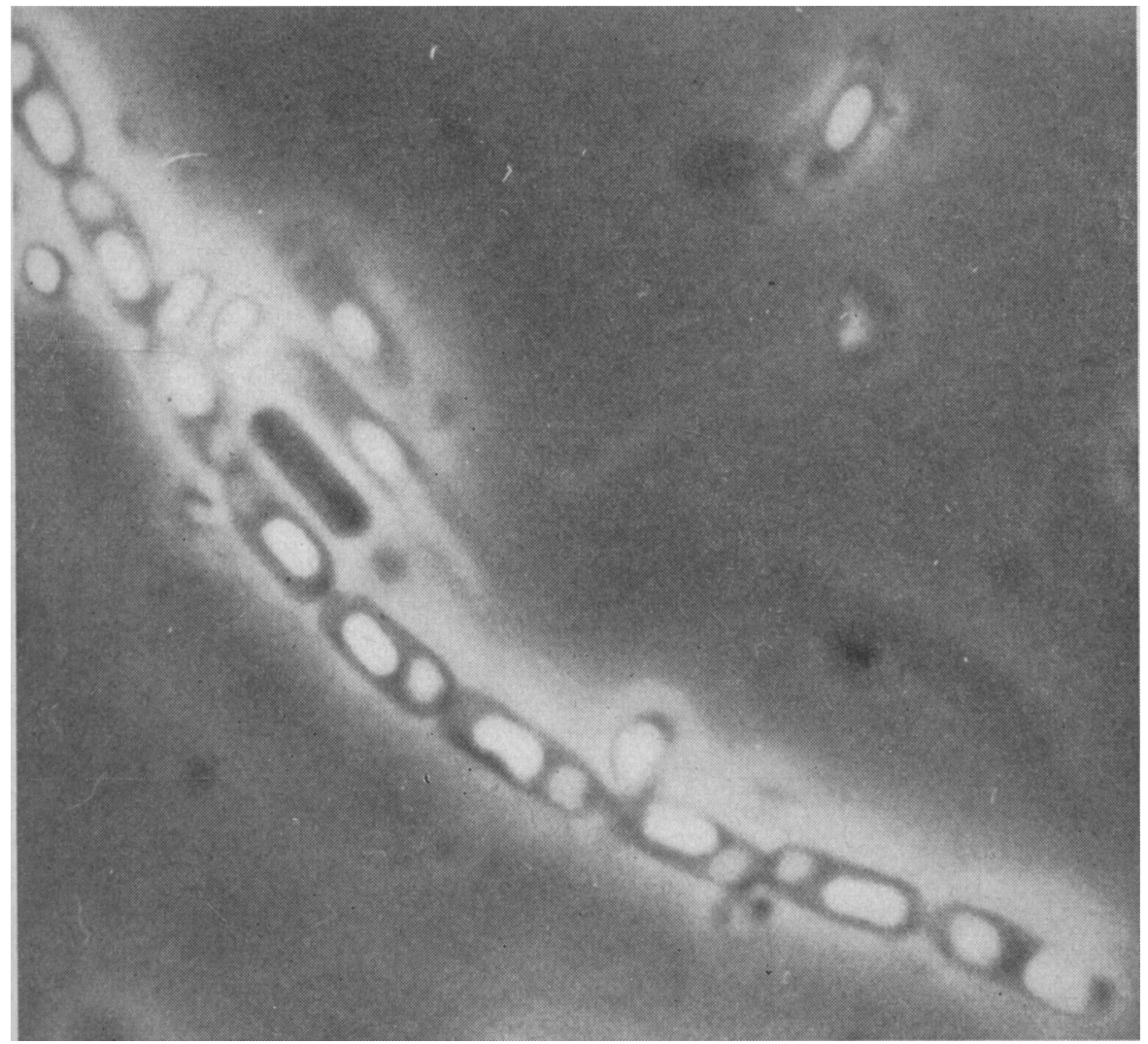

Fig. 14. Strain 57-1-1. 


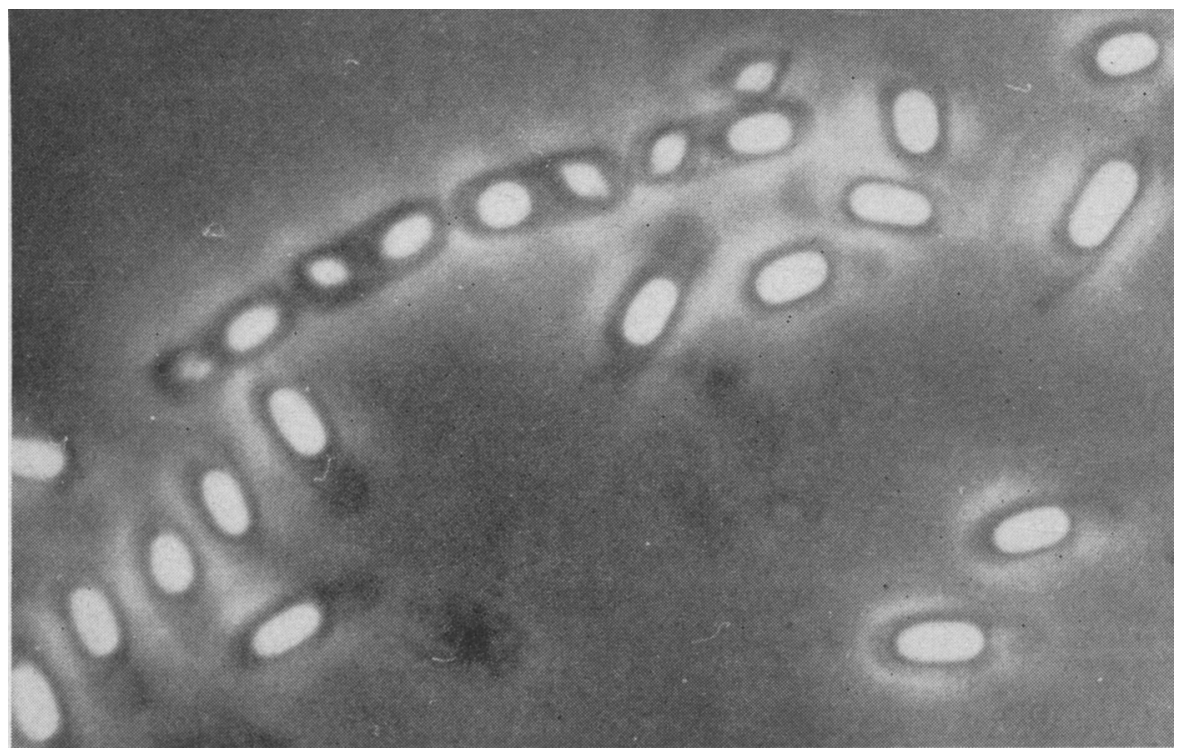

Fig. 15. Strain 0-24-1 (B. cereus var. alesti).
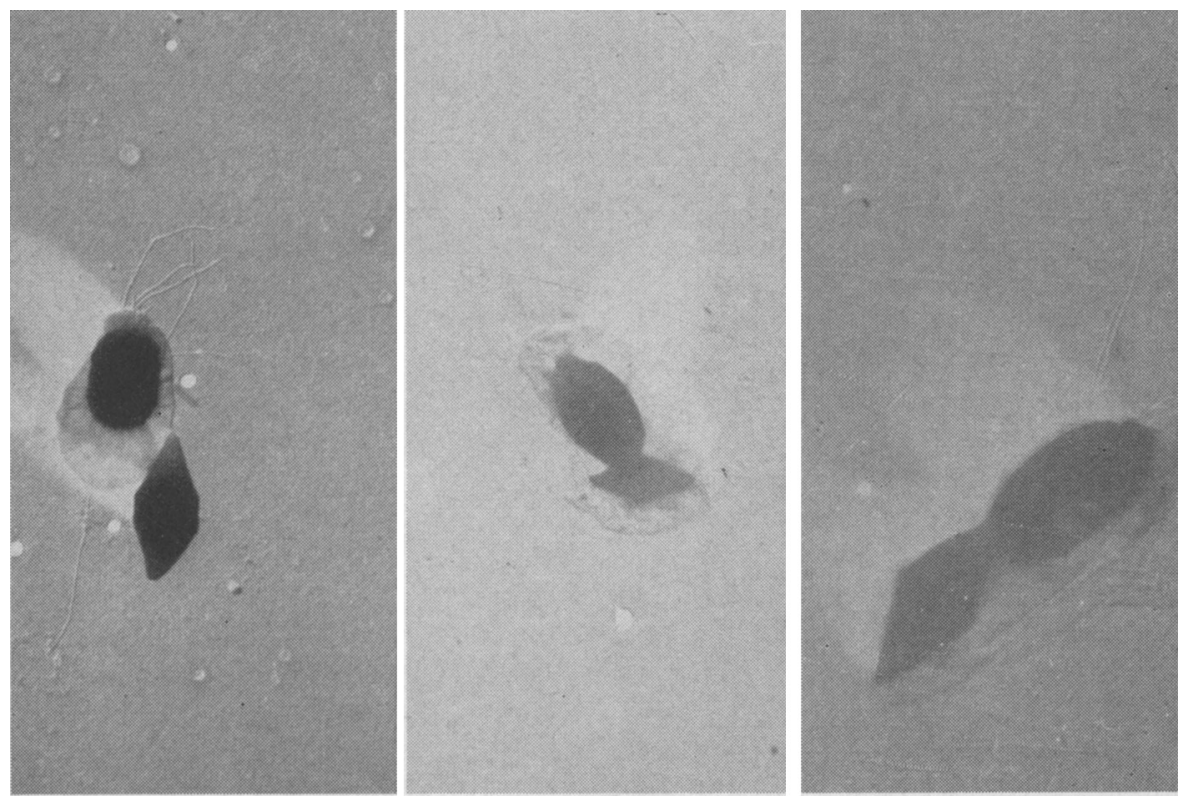

Fig. 16. Electron micrographs of the Mattes strain (0-3-30) of B. thuringiensis showing the diamond-shaped inclusion and spore. Magnification 11,200 X. 
ample, 16-1-2 and 16-2-2; figures 7, 8, 9, 10,12, and 13). We have made no crystallographic study of the inclusions and are not prepared to affirm their crystalline nature.

Most strains of $B$. thuringiensis we examined characteristically showed inclusions in virtually every sporangium. Hannay found them to be invariably present during the course of his studies. However, when we examined cultures of $B$. cereus var. alesti, the inclusions were found to accompany spore formation in only a small percentage (from 1 to 10 per cent) of the cells (fig. 15). This, as well as other slight morphological differences in the cells, caused us to suspect that probably more than one strain of sporeformer were present. Plate cultures on nutrient agar confirmed this suspicion, yielding three difficult-to-distinguish colony types differentiated largely by color: the colonies of one strain were gray, those of the second strain (the one bearing inclusions) were less gray, and those of the third were gray but were characterized by the presence of a darkappearing circular ring. When examined, upon receipt, the two transfers originally obtained from Dr. Toumanoff and Dr. Vago had completed sporulation but the free crystal-like inclusions were present and slight differences in the size and shape of the spores could be detected.

The significance of these findings, and the related infectivity tests, cannot be ascertained until further work on the strains involved has been completed. It is possible that the inclusion-bearing strain is one that became mixed with strains which do not produce inclusions. We do not have evidence that any one of the strains is a mutant or variant of another of the three, but that dissociation may have occurred is certainly a possibility. In any case, we are not implying that the French workers employed impure cultures in their experiments. Instead, we are briefly reporting our observations because they demonstrate the care that must be exercised in maintaining a strain of the B. cereus type in a "pure" state, and are reporting that from the few transfers we have made, an inclusion-bearing strain appears capable of maintaining itself in very few numbers in cultures with what appear to be other strains of sporeformers.

Hannay observed the inclusions to vary greatly in size, and Mattes records their size as 0.6 by 2.0 microns. In our preparations, considerable variation in size was noted, but the average size appeared to be about the same as that given by Mattes. Occasionally very large forms, approximately twice these dimensions, were seen (for example, note free inclusion near center of figure 2).

According to Mattes, in active cultures the inclusions disintegrate as time passes, although in desiccated cultures they can still be seen after several years. Hannay noted that for the duration of his studies the freed inclusions persist indefinitely. Although we paid no special attention to this matter in our own studies, the inclusions appeared to persist in cultures of the bacilli for at least the two- to three-week period they were observed, and several dried spore preparations made in 1949 showed them still to be present in large numbers. As observed by Hannay, dilute alkali does cause their dissolution. Incidentally, in one experiment, we found the spores of $B$. thurin- 
giensis grown in nutrient broth and dried on glass beads to remain viable for 40 months but no longer. Dried spore powder prepared in July, 1949 from growth on nutrient agar, and held at room temperatures was found to be still viable and virulent in February, 1954-almost five years after preparation.

Of considerable interest is the apparent presence, occasionally, of two inclusions in the same cell. What could logically be interpreted as such a situation was seen on a number of occasions during the microscopic examination of the inclusion-bearing strains. In so far as he observed the strains with which he worked, Hannay found only one inclusion to be formed in each cell. An attempt to photograph a cell containing two of the inclusions resulted in figure 3 (note cell to right of center). In this particular instance, however, it is possible that a freed inclusion is superimposed on an inclusioncontaining sporangium. In any case, the aspect presented resembles what we believe we have seen in reality. Probably of a similar nature are the paired bodies (perhaps in developmental stages) occurring in certain sporangia in figures 10,12, and 13. It will be noted that sometimes the two bodies are of equal size and at other times one is somewhat smaller than the other. The true nature and significance of these double inclusions remain to be ascertained.

Ordinarily the inclusion is located at or toward the opposite end of the cell from the spore. As Hannay pointed out, the spore-inclusion order in a chain of cells is random (figures $9,10,13$, and 14). Occasionally (for example, figure 2) the inclusion is forced or works its way to one side or the other of the cell and lies lateral or semilateral to the spore. At times the spore is not located near the end of the sporangium but moves toward the center; in such a location the spore and the inclusion appear in close contact (certain cells in figures 1, 2, 16, and others). Less frequently does the inclusion appear to have left its end of the cell and to have moved toward the spore end.

The electron micrographs (figure 16) referred to in the preceding paragraphs were made primarily to gain a clearer impression of the morphology of the inclusion, its density, and its relation to the endospore. Inasmuch as Dr. Hannay has generously informed us concerning his present and planned studies of the nature and function of the inclusions, as well as of their structure and content, it is not our intention to pursue further this particular aspect of our own investigations.

Nomenclature. In a previous paper the senior author (Steinhaus, 1951) discussed the nomenclature of the sporeforming bacterium designated in the present paper as Bacillus thuringiensis Berliner, and presented reasons for the tentative retention of this name to distinguish the organism from Bacillus cereus Frankland and Frankland. In 1952, however, Smith, Gordon, and Clark, in their monograph on the genus Bacillus, proposed the new combination Bacillus cereus var. thuringiensis. Shortly thereafter, in correspondence, Dr. Smith stated that whereas academically $B$. thuringiensis should be considered as a variant of $B$. cereus, "from the practical standpoint it has been thought best to retain these as separate species," at least for the present. Recently, Dr. Smith informed the authors that the forth- 
coming seventh edition of Bergey's Manual of Determinative Bacteriology will refer to the organism as a separate species and use the name Bacillus thuringiensis Berliner.

For these reasons, it has been thought best for the purposes of the present paper to maintain a conservative position and to use the name in accordance with its projected use in Bergey's Manual. To be sure, if the inclusionbearing strains of the bacillus represent strains of $B$. cereus that have been "infected" with a virus or altered in their toxinogenic properties, a nomenclatorial link to the stable parent form should be established. Under such circumstances the designation $B$. cereus var. thuringiensis would probably be preferred.

\section{SUMMARY}

The present paper represents a continuation of studies on Bacillus thuringiensis Berliner reported in 1951, plus the results of a cytological examination of 51 strains of sporeforming bacilli with respect to the "crystalline inclusions" (the "Restkörper" of earlier authors) recently described by Hannay.

Infectivity tests were run on 51 strains of sporeforming bacteria of the genus Bacillus using, as test insects, the alfalfa caterpillar, Colias philodice eurytheme Boisd., and the buckeye caterpillar, Junonia coenia Hbn. In general, of the sporeformers tested, the 11 strains of $B$. thuringiensis were the most virulent. The remaining 14 strains isolated from insects showed varying degrees of pathogenicity for the test insects. None of the 26 sporeformers derived from sources other than insects possessed a significantly high degree of virulence for the insects.

Of the 51 bacterial strains examined, those classified as $B$. thuringiensis were characterized by the development of spores accompanied by the formation of the crystal-like inclusions which, according to Hannay, may be associated with the organism's virulence. Although in some strains of $B$. thuringiensis the form of the inclusions is characteristically diamond shaped, in other strains the shape may vary from rhombohedral to cubical or cuboidal. Considerable variation in the size of the inclusions was noted. Sometimes two of the inclusions are seen within a sporangium. The inclusions are freed from the cells along with the spores and appear to persist indefinitely. Dried spore preparations, still viable after almost five years, contained large numbers of the inclusions. 


\section{LITERATURE CITED}

ANGUS, T. A.

1953. Studies of Bacillus spp. pathogenic for silkworm. Bi-monthly Progress Report. Canada Dept. Agr., Sci. Service, Forest Bio. Div. 9, Nov.-Dec., 1-2.

BERLiner, E.

1915. Über die Schlaffsucht der Mehlmottenraupe (Ephestia kühniella, Zell.) und ihren Erreger Bacillus thuringiensis, n. sp. Ztschr. f. Angew. Ent. 2:29-56.

Chorine, V.

1929. New bacteria pathogenic to the larvae of Pyrausta nubilalis Hbn. Internatl. Corn Borer Invest. Sci. Rpts. 2:39-53.

Clark, E. C.

1954. Unpublished observations.

DUTKY, S. R.

1942. Method for the preparation of spore-dust mixtures of Type A milky disease of Japanese beetle larvae for field inoculation. U.S. Dept. Agr., Entomol. \& Plant Quarantine, ET-192, $10 \mathrm{pp}$.

Ellinger, T., and V. Chorine

1930. Note on the bacteria isolated from Ephestia kühniella Zell. Internatl. Corn Borer Invest. Sci. Rpts. 3:37-38.

Faldini, J. D., and J. A. Pastrana

1952. Bacillus thuringiensis como agente entomofago de "Colias lesbia." Rev. Argentina de Agron. 19:154-65.

HALL, I. M.

1954. Studies of microorganisms pathogenic to the sod webworm. Hilgardia 22(15): $535-65$.

Hannay, C. L.

1953. Crystalline inclusions in aerobic sporeforming bacteria. Nature 172:1004.

Husz, B.

1928. Bacillus thuringiensis Berl., a bacterium pathogenic to corn borer larvae. Internatl. Corn Borer Invest. Sci. Rpts. 1:191-93.

Mattes, O.

1927. Parasitäre Krankheiten der Mehlmottenlarven und Versuche über ihre Verwendbarkeit als biologische Bekämpfungsmittel. (Zugleich ein Beitrag zur Zytologie der Bakterien.) Gesell. f. Beförd. Gesam. Naturw. Sitzber. [Marburg] $62: 381-417$.

Metalnikov, S., and V. Chorine

1929a. On the infection of the gypsy moth and certain other insects with Bacterium thuringiensis. A preliminary report. Internatl. Corn Borer Invest. Sei. Rpts. 2: $60-61$.

1929b. L'utilisation des microbes dans la lutte contre la pyrale du maïs. Inst. Pasteur Ann. [Paris] 43: 1391-95.

SHEPHERD, D.

1924. Life history and biology of Echocerus cornutus (Fab.). Jour. Econ. Ent. 17: 572-77.

SMith, N. R., R. E. Gordon, and F. E. Clark

1952. Aerobic sporeforming bacteria. U. S. Dept. Agr., Agr. Monograph No. 16. 148 pp.

Sокоцоғ, V. P., and L. J. Kцотz

1942. Mortality of red scale on citrus through infection with a sporeforming bacterium. Phytopathology 32:187-98. 
Steinhaus, E. A.

1946. Insect microbiology. 763 pp. Comstock Pub. Co., Inc., Ithaca, N. Y.

1949. Principles of insect pathology. 757 pp. McGraw-Hill Book Co., Inc., New York.

1951. Possible use of Bacillus thuringiensis Berliner as an aid in the biological control of the alfalfa caterpillar. Hilgardia 20(18):359-81.

1952. Microbial infections in European corn borer larvae held in the laboratory. Jour. Econ. Ent. 45:48-51.

1953. Diseases of insects reared in the laboratory or insectary. California Univ. Pubs. Agr. Sci. Leaflet No. 9. 26 pp.

Steinhaus, E. A., and C. R. Bell

1953. The effect of certain microorganisms and antibiotics on stored-grain insects. Jour. Econ. Ent. 46:582-98.

STEPHENS, June M.

1952. Disease in codling moth larvae produced by several strains of Bacillus cereus. Canadian Jour. Zool. 30:30-40.

TANADA, Y.

1953. Susceptibility of the imported cabbage worm to Bacillus thuringiensis Berliner. Hawaiian Ent. Soc. Proc. 15: 159-66.

Thompson, C. G.

1954. The use of certain entomogenous microörganisms to control the alfalfa caterpillar. Jour. Econ. Entomol. (In press.)

Toumanofr, C.

1953. Description de quelques souches entomophytes de Bacillus cereus Frank. et Frank., avec remarques sur leur action et celle d'autres bacilles sur le jaune d'oeuf. Inst. Pasteur Ann. [Paris] 85:90-98.

Toumanoff, C., and C. VAGo

1951. L'agent pathogène de la flacherie des vers à soie endémique dans la région des Cévennes: Bacillus cereus var. alesti var. nov. Compt. Rendus Acad. Sci. 233: 1504-06.

1952a. La nature de l'affection des vers à soie due a Bacillus cereus var. alesti Toum. et Vago et les modalités d'action de ce bacille. Inst. Pasteur Ann. [Paris] 83: 421-22.

1952b. Essais comparatifs sur la virulence pour Bombyx mori L. (Lepidoptera) de divers bacilles entomophytes du groupe cereus. Inst. Pasteur Ann. [Paris] 83: 634-39.

1952c. L'effet de l'alcalinité du milieu de culture sur la virulence de Bacillus cereus var. alesti Toum. et Vago, pour les vers à soie. Compt. Rendus Acad. Sci. 235:1715-17.

1953. Etude histopathologique des vers à soie atteints de Bacillus cereus var. alesti. Inst. Pasteur Ann. [Paris] 84:376-85. 


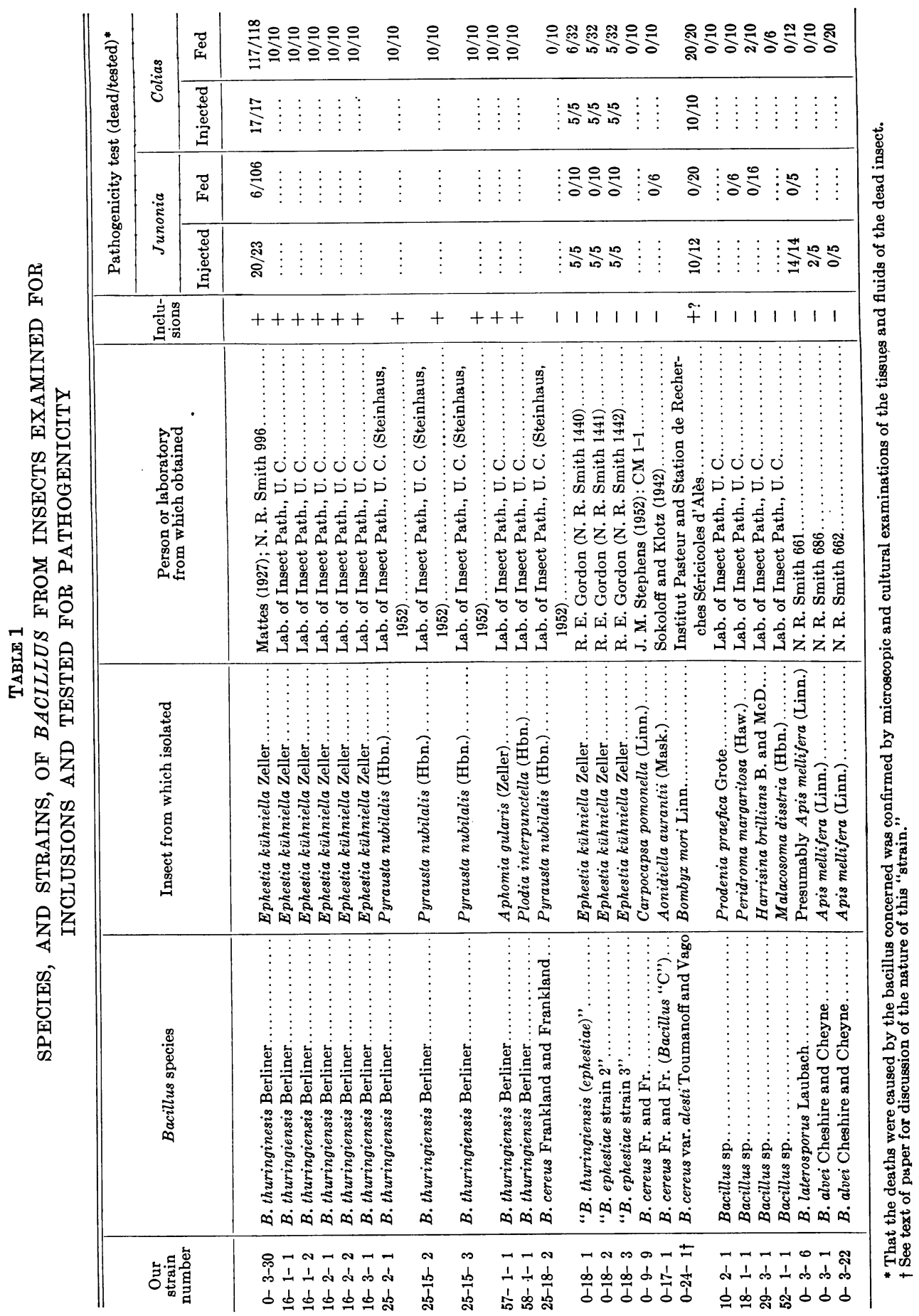




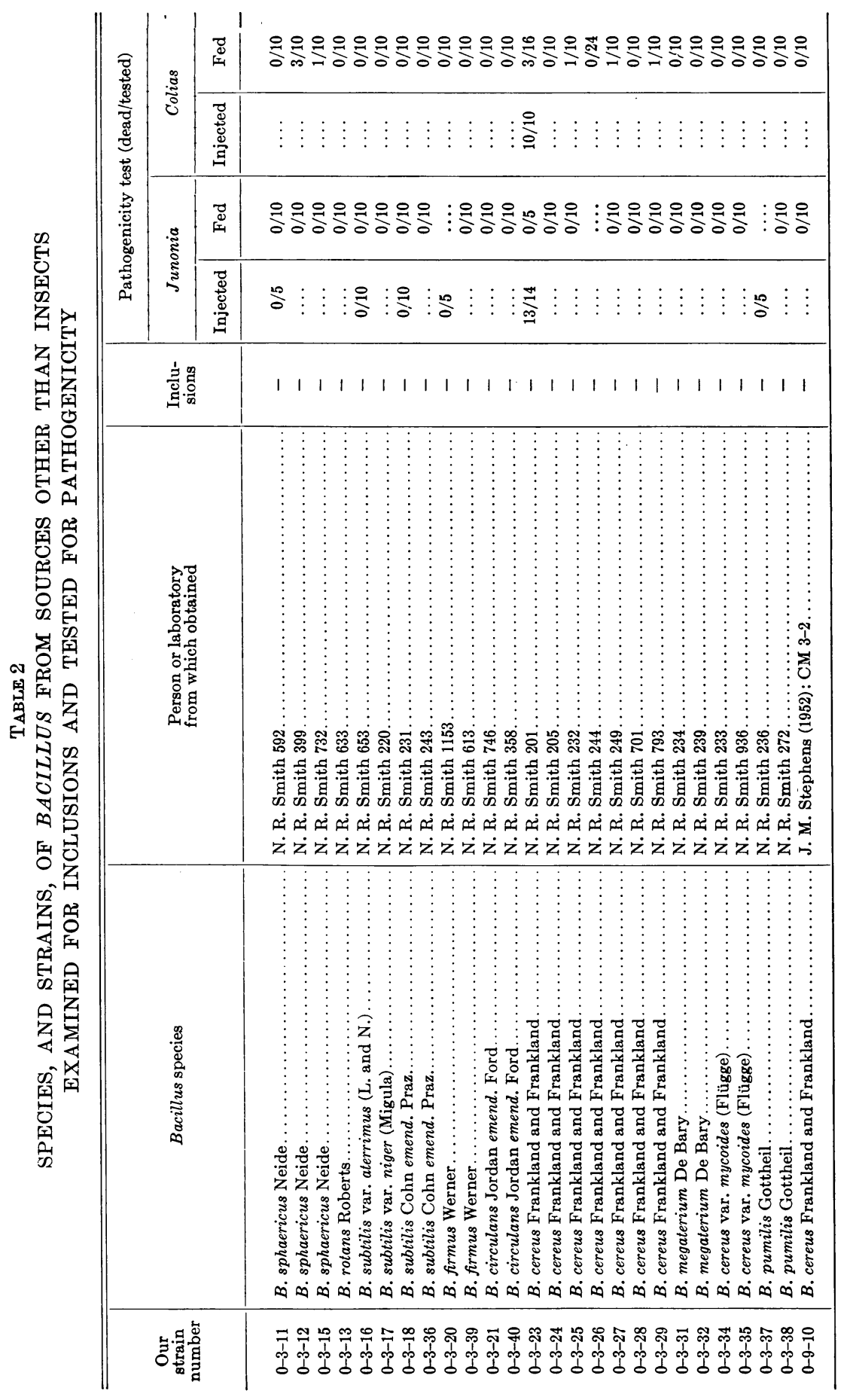



The journal Hilgardia is published at irregular intervals, in volumes of about 600 pages. The number of issues per volume varies.

Subscriptions are not sold. The periodical is sent as published only to libraries, or to institutions in foreign countries having publications to offer in exchange.

You may obtain a single copy of any issue free, as long as the supply lasts; please request by volume and issue number from:
Agricultural Publications
Room 22, Giannini Hall
College of Agriculture
Berkeley 4, California

The limit to nonresidents of California is 10 separate issues on a single order. A list of the issues still available will be sent on request. 